\title{
KARAKTERISTIK BEBERAPA SIFAT FISIKA TANAH AKIBAT PEMBERIAN PUPUK ORGANIK, BIOCHAR, NPK DAN POLA TANAM JAGUNG DAN KEDELAI
}

\section{SOME CHARACTERISTICS OF THE PHYSICAL PROPERTIES OF THE SOIL DUE TO THE GRANTING OF ORGANIC FERTILIZERS, NPK AND PATTERNS OF BIOCHAR, PLANTING CORN AND SOYBEANS}

\author{
Mukhsin Febi Mirza ${ }^{1}$, Hairul Basri ${ }^{2 *}$, Teti Arabia ${ }^{2}$ \\ ${ }^{1}$ Program Studi Agroteknologi, Fakultas Pertanian, Universitas Syiah Kuala \\ ${ }^{2}$ Program Studi Ilmu Tanah Fakultas Pertanian, Universitas Syiah Kuala \\ *corresponding author: hairulbasri@unsyiah.ac.id
}

\begin{abstract}
ABSTRAK
Abstrak. Penelitian ini bertujuan untuk mengetahui pengaruh pemberian pupuk organik, biochar, NPK dan pola tanam jagung dan kedelai terhadap karakteristik fisika tanah. Penelitian ini dilaksanakan pada Agustus sampai Februari 2017 di kecamatan Muara Tiga kabupaten Pidie. Penelitian menggunakan Rancangan Acak Kelompok (RAK) pola faktorial $5 \times 3$ dengan 3 ulangan. Faktor yang diteliti adalah pembenah tanah (A) dan pola tanam (S). factor pertama pembenah tanah (A) terdiri dari NPK $400 \mathrm{~kg} \mathrm{ha}^{-1}$, biochar $10 \mathrm{t} \mathrm{ha}^{-1}$, pupuk kandang $10 \mathrm{t} \mathrm{ha}^{-1}$, biochar $10 \mathrm{t} \mathrm{ha}^{-1}+$ NPK $400 \mathrm{~kg} \mathrm{ha}^{-1}$, pupuk kandang $10 \mathrm{t} \mathrm{ha}^{-1}+$ NPK $400 \mathrm{~kg} \mathrm{ha}^{-1}$, faktor kedua adalah pola tanam yaitu monokultur jagung, monokultur kedelai, tumpangsari jagung dan kedelai dengan demikian terdapat 15 kombinasi perlakuan dengan 3 ulangan. Parameter yang diamati adalah porositas tanah, indeks stabilitas agregat, dan kadar air tanah. Hasil penelitian menunjukkan bahwa pupuk organik, biochar, NPK dan pola tanam memberikan efek yang sama yaitu tidak berpengaruh nyata terhadap porositas tanah, indeks stabilitas agregat dan kadar air tanah. Namun terdapat interaksi antara perlakuan pupuk organik, biochar, NPK dan pola tanam terhadap porositas tanah dan indeks stabilitas agregat.
\end{abstract}

Kata kunci : biochar, pupuk organik, pola tanam, tumpangsari jagung dan kedelai,

\begin{abstract}
This research aims to know the influence of the giving of the organic fertilizer, NPK and patterns of biochar, planting corn and soybeans against the physical characteristics of the soil. This research was carried out in August until February 2017 in the subdistrict of Muara Tiga Pidie. The research of using Random Design Group (RAK) factorial pattern $5 \times 3$ with 3 replicates. Factors examined are (A) the land pembenah and the planting pattern (S). the first factor pembenah the soil (A) consists of $400 \mathrm{~kg}$ of NPK ha-1, biochar $10 \mathrm{tha}-1$, manure $10 \mathrm{t}$ ha-1, biochar $10 \mathrm{t}$ ha-1 + NPK $400 \mathrm{~kg}$ ha-1, manure $10 \mathrm{t}$ ha-1 + NPK $400 \mathrm{~kg}$ ha-1, the second factor is the pattern of planting corn monoculture, namely soy monoculture intercropping of corn and soybeans, thus there are 15 combination treatment with 3 replicates. The observed parameters are porosity, soil aggregate stability index, and moisture content of the soil. The results showed that the organic fertilizer, biochar, NPK and planting patterns give the same effect that is not the real effect against porosity soil aggregate stability index, and moisture content of the soil. However, there is an interaction between treatment of organic fertilizer, biochar, NPK and planting patterns against the porosity of soil aggregate stability and index.
\end{abstract}

Keywords: biochar, organic fertilizers, cropping patterns, intercropping of maize and soybean

\section{PENDAHULUAN}

Tanah memiliki sifat yang bervariasi, yaitu terdiri dari sifat fisik, kimia dan biologi. Dengan bervariasinya sifat-sifat tersebut, maka tingkat kesuburan pada berbagai jenis tanah berbeda-beda pula, karena kesuburan suatu tanah tergantung pada sifat-sifat tersebut. Oleh sebab itu diperlukan pemahaman mengenai karakteristik tanah sehingga dapat dimanfaatkan sesuai dengan potensinya (Balai Penelitian Tanah, 2003; Boix and Zinck, 2008; Ferdinan et al., 2013).

Usaha pengawetan tanah dan air dapat dilakukan dengan berbagai cara, seperti dengan pemberian bahan organik pada lahan pertanian dan penanaman tanaman penutup tanah. Pemberian bahan organik pada tanah dapat meningkatkan unsur hara dan memperbaiki sifat- 
sifat fisik tanah, seperti porositas, struktur tanah, permeabilitas tanah dan daya menahan air (Hardjowigeno, 2007).

Pemberian pupuk organik dapat memperbaiki struktur tanah, menaikan bahan serap tanah terhadap air, menaikan kondisi kehidupan di dalam tanah, dan sebagai sumber zat makanan bagi tanaman. Sedangkan pemberian pupuk anorganik dapat merangsang pertumbuhan secara keseluruhan khususnya cabang, batang, daun, dan berperan penting dalam pembentukan hijau daun (Lingga, 2008).

Pupuk organik adalah pupuk yang dapat berbentuk padat atau cair yang berasal dari tanaman dan atau hewan. Digunakan pupuk organik sebagai alternatif dari penggunaann pupuk anorganik, karena selain dapat memperbaiki sifat fisik, kimia dan biologi tanah, pupuk organik secara ekonomis jauh lebih terjangkau dari pupuk anorganik, sehingga dapat mengurangi biaya produksi pertanian (Lingga dan Marsono, 2007).

Biochar merupakan bentuk karbon stabil yang dihasilkan dari proses pirolisis bahanbahan organik. Saat ini biochar sangat diminati karena sangat berpotensi untuk meningkatkan kesuburan tanah, meningkatkan hasil panen dan mampu menyerap serta menyimpan karbon (C) dalam tanah. Biochar terbukti stabil dan efektif sebagai cadangan karbon. Dalam biochar, karbon terbentuk dari proses pirolisis sehingga tidak mudah terdegradasi oleh aktifitas mikroba seperti biomassa lain yang mengandung karbon tingkat rendah. Kualitas biochar tergantung dari jenis bahan dan karakteristik bahan yang digunakan (Shenbagavalli dan Mahimairaja, 2012).

Tujuan

Penelitian ini bertujuan untuk mengetahui perubahan karakteristik sifat fisika tanah dengan menggunakan pupuk organik dan biochar yang dikombinasikan dengan pupuk NPK serta budidaya tumpang sari jagung dan kedelai.

\section{METODE PENELITIAN}

\section{Tempat dan Waktu}

Penelitian ini dilaksanakan di Desa Pawood Kecamatan Muara Tiga Kabupaten Pidie Provinsi Aceh pada bulan Agustus sampai Desember 2016,

\section{Alat dan Bahan}

Alat yang digunakan dalam penelitian ini cangkul, ring sampel, kantong plastik, cawan, timbangan analitik, jam, kamera, digital, oven, pressure plate apparatus, ayakan, pisau lapang, penggaris ukur, karet gelang, kertas label, eksikator, cawan aluminium, kertas saring, keramik plate, permeameter, stopwatch.

Bahan yang digunakan dalam penelitian ini antara lain tanah yang diambil dengan menggunakan Ring Sample, pupuk NPK Phonska, biochar sekam padi, pupuk kandang sapi, benih kedelai varietas Dena dan benih jagung varietas Bonanza.

\subsection{Rancangan Penelitian}

Penelitian ini dilaksanakan dengan metode eksperimen dan analisis laboratorium menggunakan rancangan acak kelompok (RAK) dengan pola faktorial 5 x 3 dengan tiga ulangan. Adapun faktor yang diteliti yaitu pembenah tanah (A) dan pola tanam (S).

Faktor I : Pembenah tanah

$$
\begin{aligned}
& \text { A0 }=\text { NPK } 400 \mathrm{~kg} \mathrm{ha}^{-1} \\
& \text { A1 }=\text { Biochar } 10 \text { ton ha }{ }^{-1} \\
& \text { A2 }=\text { Pupuk kandang } 10 \text { ton ha } \\
& \text { A3 }=\text { Biochar } 10 \text { ton ha- }{ }^{-1}+\text { NPK } 400{\text { ton } \mathrm{ha}^{-1}} \\
& \text { A4 }=\text { Pupuk kandang } 10 \text { ton ha- }{ }^{1}+\text { NPK } 400 \mathrm{~kg} \mathrm{ha}^{-1}
\end{aligned}
$$


Faktor II : Pola tanam

S1 = monokultur jagung

$\mathrm{S} 2=$ monokultur kedelai

S3 = Tumpangsari jagung dan kedelai

Dengan demikian terdapat 15 kombinasi perlakuan dengan tiga ulangan dapat dilihat pada Tabel 1.

Tabel 1. Kombinasi perlakuan di desa Pawood Laweung Pidie

\begin{tabular}{|c|c|c|c|}
\hline No & Kombinasi & Faktor I & Faktor II \\
\hline 1 & A0S1 & NPK $400 \mathrm{~kg} \mathrm{ha}^{-1}$ & Monokultur Jagung \\
\hline 2 & A0S2 & NPK $400 \mathrm{~kg} \mathrm{ha}^{-1}$ & Monokultur Kedelai \\
\hline 3 & A0S3 & NPK $400 \mathrm{~kg} \mathrm{ha}^{-1}$ & Tumpangsari Jagung dan Kedelai \\
\hline 4 & A1S1 & Biochar 10 ton $\mathrm{ha}^{-1}+\mathrm{NPK} 400 \mathrm{~kg} \mathrm{ha}^{-1}$ & Monokultur Jagung \\
\hline 5 & A1S2 & Biochar 10 ton $\mathrm{ha}^{-1}+$ NPK $400 \mathrm{~kg} \mathrm{ha}^{-1}$ & Monokultur Kedelai \\
\hline 6 & A1S3 & Biochar 10 ton $\mathrm{ha}^{-1}+$ NPK $400 \mathrm{~kg} \mathrm{ha}^{-1}$ & Tumpangsari Jagung dan Kedelai \\
\hline 7 & $\mathrm{~A} 2 \mathrm{~S} 1$ & Pupuk kandang 10 ton $\mathrm{ha}^{-1}+$ NPK $400 \mathrm{~kg} \mathrm{ha}^{-1}$ & Monokultur Jagung \\
\hline 8 & $\mathrm{~A} 2 \mathrm{~S} 2$ & Pupuk kandang 10 ton $\mathrm{ha}^{-1}+$ NPK $400 \mathrm{~kg} \mathrm{ha}^{-1}$ & Monokultur Kedelai \\
\hline 9 & $\mathrm{~A} 2 \mathrm{~S} 3$ & Pupuk kandang 10 ton $\mathrm{ha}^{-1}+$ NPK $400 \mathrm{~kg} \mathrm{ha}^{-1}$ & Tumpangsari Jagung dan Kedelai \\
\hline 10 & A3S1 & Biochar 10 ton $\mathrm{ha}^{-1}+$ NPK $400 \mathrm{~kg} \mathrm{ha}^{-1}$ & Monokultur Jagung \\
\hline 11 & $\mathrm{~A} 3 \mathrm{~S} 2$ & Biochar 10 ton $\mathrm{ha}^{-1}+$ NPK $400 \mathrm{~kg} \mathrm{ha}^{-1}$ & Monokultur Kedelai \\
\hline 12 & $\mathrm{~A} 3 \mathrm{~S} 3$ & Biochar 10 ton $\mathrm{ha}^{-1}+$ NPK $400 \mathrm{~kg} \mathrm{ha}^{-1}$ & Tumpangsari Jagung dan Kedelai \\
\hline 13 & $\mathrm{~A} 4 \mathrm{~S} 1$ & Pupuk kandang 10 ton $\mathrm{ha}^{-1}+$ NPK $400 \mathrm{~kg} \mathrm{ha}^{-1}$ & Monokultur Jagung \\
\hline 14 & A4S2 & Pupuk kandang 10 ton $\mathrm{ha}^{-1}+$ NPK $400 \mathrm{~kg} \mathrm{ha}^{-1}$ & Monokultur Kedelai \\
\hline 15 & A4S3 & Pupuk kandang 10 ton $\mathrm{ha}^{-1}+$ NPK $400 \mathrm{~kg} \mathrm{ha}^{-1}$ & Tumpangsari Jagung dan Kedelai \\
\hline
\end{tabular}

\section{Pelaksanaan Penelitian}

\section{Persiapan Lahan}

Lahan yang akan digunakan dalam penelitian ini adalah lahan kering yang berjenis tanah kambisol. Sebelum pembuatan plot penelitian terlebih dahulu akan dilakukan pengolahan tanah dengan traktor roda empat. Setelah itu lahan dibuat plot dengan ukuran 2.1 $\mathrm{m} \times 3$ 3,5 $\mathrm{m}$ dan tinggi $30 \mathrm{~cm}$ dengan jarak antar plot $70 \mathrm{~cm}$ dan jarak antar blok $1 \mathrm{~m}$ Susunan petak plot disesusaikan dengan perlakuan dan pembagian plot masing-masing sebanyak 15 unit untuk setiap blok.

\section{Pemberian pembenah tanah}

Pemberian pembenah tanah biochar sekam padi dan pupuk kandang sapi dilakukan dua minggu sebelum tanam, sedangkan NPK phonska diberikan sebanyak dua kali yaitu saat tanam dengan dosis perlakuan dan 45 HST sesuai dosis perlakuan. Aplikasi pemberian pembenah tanah untuk masing-masing plot perlakukan yaitu biochar sekam padi sebanyak $7.35 \mathrm{~kg} /$ plot, pupuk kandang sebanyak $7.35 \mathrm{~kg}$ plot dan NPK Phonska sebanyak $294 \mathrm{gr} /$ plot.

\section{Penanaman}

Penanaman dilakukan dengan membuat lubang tanam $\pm 3 \mathrm{~cm}$ dan tiap lubang diisi 2 benih. Jarak tanam sesuai dengan perlakuan yaitu $\mathrm{S}_{1}=$ monokultur kedelai dengan jarak tanam $30 \times 30 \mathrm{~cm}, \mathrm{~S}_{2}=$ monokultur jagung dengan jarak tanam $70 \times 30 \mathrm{~cm}, \mathrm{~S}_{3}=$ tumpang sari jagung-kedelai dengan jarak 35 x $30 \mathrm{~cm}$. Penanaman jagung dilakukan 14 hari setelah penanaman kedelai dengan pola tanaman satu jalur jagung diselingi dengan satu jalur kedelai. 


\section{Pemupukan}

Pemupukan yang diberikan adalah pupuk NPK Phonska $400 \mathrm{~kg} \mathrm{ha}^{-1}$ sesuai perlakuan, pada saat tanam dengan cara larikan.

\section{Pemeliharaan}

Pemelihraan tanaman dilakukan untuk menjaga agar tanaman tetap tumbuh baik selama waktu percobaan. Pemeliharaan yang dilakukan antara lain penyiraman, penyiangan gulma dan pengendalian OPT, Penyiraman tanaman dilakukan pagi dan sore hari sesuai kondisi cuaca. Penyiangan gulma dilakukan dengan cara mencabut. Pengendalian OPT dilakukan jika serangan telah mencapai ambang batas ekonomi dengan menyemprot bagian tanaman dengan pestisida menggunakan hand sprayer.

\section{Panen}

Pemanenan tanaman jagung dilakukan pada saat rambut kelobot tanaman jagung telah berwarna kecoklatan. Untuk pemanenan kedelai dilakukan pada saat tanaman mengering, berwarna kuning, batang mulai mengeras, polong keras, dan berubah warna menjadi kecoklatan dan dilakukan dengan cara memotong pangkal dengan sabit.

\section{Tahap Pengambilan Data di Lapangan}

Tahap pengambilan data di lapangan yaitu pengambilan contoh tanah untuk sifat fisika tanah pada kedalaman 0-20 $\mathrm{cm}$ dengan menggunakan ring sampel pada tiap plot penelitian. Pengambilan contoh tanah utuh ini dilakukan sebanyak satu titik pada setiap petak contoh dalam jalur tanam. Pengamatan dalam perlakuan ini meliputi perubahan sifat fisika tanah. Parameter dan analisis sifat fisika tanah disajikan pada Tabel 2.

Tabel 2. Parameter dan metode analisis sifat fisika tanah

\begin{tabular}{cll}
\hline No & Parameter Analisis & Metode \\
\hline 1 & Porositas Tanah & Tinggi Muka Air Permukaan \\
2 & Indeks Stabilitas Agregat & Pengayakan Kering dan basah \\
3 & Kadar Air & Pressure Plate apparatus \\
\hline
\end{tabular}

\section{HASIL DAN PEMBAHASAN}

\section{Porositas}

\section{Pengaruh Pembenah Tanah dan Pola Tanam terhadap porositas tanah}

Hasil analisis ragam menunjukkan bahwa perlakuan pembenah tanah dan pola tanam tidak berpengaruh nyata terhadap nilai porositas. Rata-rata nilai porositas akibat perlakuan pembenah tanah dan pola tanam dapat dilihat pada Tabel 3 dan 4.

Tabel 3. Rata-rata nilai porositas akibat pengaruh pembenah tanah

\begin{tabular}{|c|c|}
\hline \multirow{2}{*}{ Perlakuan Pembenah Tanah } & Sifat Fisika Tanah \\
\hline & Porositas Tanah $(\%)$ \\
\hline NPK $400 \mathrm{~kg} \mathrm{ha}^{-1}$ & 41,84 \\
\hline Biochar 10 ton $\mathrm{ha}^{-1}$ & 42,02 \\
\hline Pupuk kandang 10 ton $\mathrm{ha}^{-1}$ & 41,73 \\
\hline Biochar 10 ton $\mathrm{ha}^{-1}+\mathrm{NPK} 400 \mathrm{~kg} \mathrm{ha}^{-1}$ & 42,04 \\
\hline Pupuk kandang 10 ton $\mathrm{ha}^{-1}+$ NPK $400 \mathrm{~kg} \mathrm{ha}^{-1}$ & 42,99 \\
\hline
\end{tabular}

BNT 0,05 
Tabel 4. Rata-rata nilai porositas akibat pengaruh pola tanam

\begin{tabular}{lc}
\hline \multirow{2}{*}{ Perlakuan Pola Tanam } & Sifat Fisika Tanah \\
\cline { 2 - 2 } & Porositas Tanah (\%) \\
\hline Monokultur Jagung & 41,63 \\
Monokultur Kedelai & 42,69 \\
Tumpangsari Jagung dan Kedelai & 42,06 \\
\hline BNT $_{\mathbf{0 , 0 5}}$ & - \\
\hline
\end{tabular}

\section{Pengaruh Interaksi perlakuan pupuk organik, biochar, NPK dan pola tanam Terhadap Porositas Tanah}

Hasil analisis ragam enunjukkan bahwa perlakuan pembenah tanah dan pola tanam berpengaruh sangat nyaata terhadap nilai porositas. Nilai rata-rata porositas akibat interaksi perlakuan pembenah tanah dan pola tanam dapat dilihat pada Tabel 5.

Tabel 5. Rata-rata nilai porositas tanah akibat interaksi pembenah tanah dan pola tanam

\begin{tabular}{|c|c|c|c|}
\hline \multirow{2}{*}{ Pembenah Tanah } & Jagung & kedelai & Tumpangsari \\
\hline & \multicolumn{3}{|c|}{ Porositas tanah $(\%)$} \\
\hline \multirow[t]{2}{*}{ NPK $400 \mathrm{~kg} \mathrm{ha}^{-1}$} & $43,41 \mathrm{a}$ & $42 ., 91 \mathrm{a}$ & $45,42 \mathrm{~b}$ \\
\hline & A & A & B \\
\hline \multirow[t]{2}{*}{ Biochar 10 ton $\mathrm{ha}^{-1}$} & $43,15 \mathrm{a}$ & $45,91 \mathrm{~b}$ & $43,22 \mathrm{ab}$ \\
\hline & A & $\mathrm{B}$ & A \\
\hline \multirow[t]{2}{*}{ Pupuk kandang 10 ton $\mathrm{ha}^{-1}$} & $43,73 \mathrm{ab}$ & $43,02 \mathrm{ab}$ & $44,65 \mathrm{~b}$ \\
\hline & A & A & A \\
\hline \multirow[t]{2}{*}{ Biochar 10 ton $\mathrm{ha}^{-1}+\mathrm{NPK} 400 \mathrm{~kg} \mathrm{ha}^{-1}$} & $44,17 \mathrm{a}$ & $44,97 \mathrm{~b}$ & $43,20 \mathrm{a}$ \\
\hline & A & A & A \\
\hline \multirow{2}{*}{$\begin{array}{l}\text { Pupuk kandang10 ton } \mathrm{ha}^{-1}+\text { NPK } 400 \\
\mathrm{~kg} \mathrm{ha}^{-1}\end{array}$} & $44,03 \mathrm{a}$ & $46,98 \mathrm{~b}$ & $44,18 \mathrm{ab}$ \\
\hline & A & $\mathrm{B}$ & A \\
\hline BNT 0,05 & 2,07 & 2,07 & 2,07 \\
\hline
\end{tabular}

Keterangan : Angka-angka yang diikuti huruf yang sama (huruf besar dibaca vertikal, huruf kecil dibaca horizontal) menunjukkan tidak berbeda nyata menurut $\mathrm{Uji}_{\mathrm{BNT}} \mathrm{BN}_{0,0}$

Tabel 5 menunjukkan bahwa nilai rata-rata interaksi porositas tertinggi dijumpai pada perlakuan pupuk kandang 10 ton $\mathrm{ha}^{-1}+\mathrm{NPK} 400 \mathrm{~kg} \mathrm{ha}^{-1}$ yaitu 48,98\% sementara nilai porositas terendah dengan presentase ruang pori $42,91 \%$ dijumpai pada perlakuan NPK 400 $\mathrm{kg} \mathrm{ha}^{-1}$ yang berbeda nyata dengan perlakuan lainnya. Hasil interksi perlakuan pembenah tanah dan pola tanam menunjukkan kriteria nilai porositas tanah pada kelas 5 yakni kurang baik untuk tanaman. Seperti yang dikemukakan Hardjowigeno (2003) porositas tanah dipengaruhi oleh kandungan bahan organik, struktur tanah, dan tekstur tanah. Porositas tanah tinggi kalau bahan organik tinggi tanah dengan struktur granuler/remah, mempunyai porositas yang tinggi daripada tanah-tanah dengan struktur massive/pejal. Tanah dengan tekstur pasir banyak mempunyai pori-pori makro sehingga sulit menahan air.

Hal lain diduga perlakuan pembenah tanah pupuk kandang sapi belum terurai sempurna seperti yang dikemukakan oleh Sutedjo dan Kartasapoetra (1990) bahwa pupuk kandang sapi termasuk pupuk kandang yang bersifat dingin sehingga perubahan-perubahan yang berlangsung terjadi secara perlahan-lahan. Oleh karena itu, pupuk kandang sapi ini sebaiknya dimanfaatkan pada tanah yang ringan bakteri dan jasad reniknya yang intensif dapat berperan memperbaiki porositas tanah.

Lebih lanjut Mulyani (2002) mengemukakan bahwa pupuk kandang sapi merupakan pupuk kandang padat yang banyak mengandung air dan lendir. Pupuk yang demikian bila 
terpengaruh oleh udara maka akan terjadi pergerakan-pergerakan sehingga keadaannya menjadi keras, selanjutnya air tanah dan udara yang akan melapukkan pupuk itu menjadi sukar merembes kedalamnya.

Interaksi pola tanam berpengaruh terhadap perubahan sifat porositas tanah terdapat pada perlakuan monokultur kedelai hal ini dikarenakan kedelai memiliki sistim akar tunggang dan akar serabut yang menyebabkan terbuka ruang-ruang pori tanah akibat pertumbuhan akar tersebut. Hal ini sejalan yang dikemukakan oleh Adisarwanto, (2005) sistem perakaran kedelai terdiri dari dua macam yaitu akar tunggang dan akar sekunder (serabut) yang tumbuh dari akar tunggang. Kedelai juga memiliki akar adventif yang tumbuh dari bagian bawah hipokotil. Perkembangan akar kedelai dipengaruhi oleh kondisi fisik dan kimia tanah, jenis tanah, cara pengolahan lahan, kecukupan unsur hara serta ketersedian air di dalam tanah. Pertumbuhan akar tunggang dapat mencapai panjang sekitar $2 \mathrm{~m}$ atau lebih, akar-akar sampingnya menyebar mendatar sejauh $2,5 \mathrm{~m}$ pada kondisi yang optimal. Umumnya akar tunggang hanya tumbuh pada kedalaman lapisan tanah olahan yang tidak terlalu dalam sekitar $30-50 \mathrm{~cm}$. Sementara akar serabut dapat tumbuh pada kedalaman tanah sekitar $20-30 \mathrm{~cm}$. Akar serabut ini mula-mula tumbuh di dekat ujung akar tunggang, sekitar 3-4 hari setelah berkecambah.

Hakim (2006) panjang akar erat hubungannya dengan tingkat kepadatan tanah, ukuran pori dan jumlah pori total tanah. Kepadatan tanah yang tinggi dapat menyebabkan total ruang pori tanah menjadi rendah. Hal ini mengakibatkan pertukaran udara dalam tanah menjadi terganggu karena celah pori yang digunakan sebagai tempat pertukaran udara dalam tanah menjadi sedikit atau sempit. Pemadatan tanah juga menyebabkan air dan udara sulit disimpan dan ketersediannya dalam tanah menjadi terbatas sehingga menyebabkan terhambatnya pernafasan akar dan penyerapan air.

\section{Indeks Stabilitas Agregat}

\section{Pengaruh Pembenah Tanah dan pola tanam terhadap Indeks Stabilitas Agregat}

analisis ragam menunjukkan bahwa perlakuan pupuk organik, biochar, NPK dan pola tanam tidak berpengaruh nyata terhadap nilai indeks stabilitas agregat. Namun terdapat interaksi antara perlakuan pupuk organik, biochar, NPK dan pola tanam

Tabel 6. Rata-rata nilai indeks stabilitas agregat akibat pengaruh pembenah tanah.

\begin{tabular}{|c|c|}
\hline Perlakuan & $\begin{array}{c}\text { Sifat Fisika Tanah } \\
\text { Indeks stahilitas aoreogt \% }\end{array}$ \\
\hline Pembenah Tanah & \\
\hline NPK $400 \mathrm{~kg} \mathrm{ha}^{-1}$ & 49,26 \\
\hline Biochar 10 ton $\mathrm{ha}^{-1}$ & 49,50 \\
\hline Pupuk kandang 10 ton $\mathrm{ha}^{-1}$ & 49,36 \\
\hline Biochar 10 ton $\mathrm{ha}^{-1}+\mathrm{NPK} 400 \mathrm{~kg} \mathrm{ha}^{-1}$ & 50,95 \\
\hline Pupuk kandang 10 ton $\mathrm{ha}^{-1}+$ NPK $400 \mathrm{~kg} \mathrm{ha}^{-1}$ & 50,57 \\
\hline BNT $_{0.05}$ & - \\
\hline
\end{tabular}


Tabel 7. Rata-rata nilai indeks stabilitas agregat akibat pengaruh pola tanam.

\begin{tabular}{lc}
\hline \multicolumn{1}{c}{ Perlakuan } & Sifat Fisika Tanah \\
\cline { 2 - 2 } & \\
\hline Pola Tanam & Indeks stabilitas agregat \% \\
Monokultur Jagung & 49,47 \\
Monokultur Kedelai & 50,97 \\
Tumpangsari Jagung dan Kedelai & 49,35 \\
\hline BNT $\mathbf{0 , 0 5}$ & - \\
\hline
\end{tabular}

\section{Pengaruh Interaksi perlakuan pupuk organik, biochar, NPK dan pola tanam Terhadap Indeks Stabilitas Agregat}

Tabel 8. Rata-rata nilai indeks stabilitas agregat akibat pengaruh interaksi perlakuan pupuk organik, biochar, NPK dan pola tanam

\begin{tabular}{|c|c|c|c|}
\hline \multirow{2}{*}{ Pembenah Tanah } & Jagung & kedelai & Tumpangsari \\
\hline & \multicolumn{3}{|c|}{ Indeks stabilitas agregat $(\%)$} \\
\hline \multirow[t]{2}{*}{ NPK $400 \mathrm{~kg} \mathrm{ha}^{-1}$} & $56,06 \mathrm{ab}$ & $52,62 \mathrm{a}$ & $56,10 \mathrm{a}$ \\
\hline & A & A & A \\
\hline \multirow[t]{2}{*}{ Biochar 10 ton $\mathrm{ha}^{-1}$} & $58,66 \mathrm{~b}$ & $54,53 \mathrm{ab}$ & $52,30 \mathrm{a}$ \\
\hline & $\mathrm{B}$ & $\mathrm{AB}$ & A \\
\hline \multirow[t]{2}{*}{ Pupuk kandang 10 ton $\mathrm{ha}^{-1}$} & $51,69 \mathrm{a}$ & $57,16 \mathrm{ab}$ & $56,21 \mathrm{a}$ \\
\hline & A & A & A \\
\hline \multirow[t]{2}{*}{ Biochar 10 ton $\mathrm{ha}^{-1}+\mathrm{NPK} 400 \mathrm{~kg} \mathrm{ha}^{-1}$} & $56,74 \mathrm{ab}$ & $58,85 \mathrm{a}$ & $54,25 \mathrm{a}$ \\
\hline & A & A & A \\
\hline \multirow{2}{*}{$\begin{array}{l}\text { Pupuk kandang10 ton } \mathrm{ha}^{-1}+\text { NPK } 400 \\
\mathrm{~kg} \mathrm{ha}^{-1}\end{array}$} & $52,50 \mathrm{ab}$ & $60,01 \mathrm{~b}$ & $56,18 \mathrm{a}$ \\
\hline & A & B & $\mathrm{AB}$ \\
\hline
\end{tabular}

BNT 0,05

Keterangan : Angka-angka yang diikuti huruf yang sama (huruf besar dibaca vertikal, huruf kecil dibaca horizontal) menunjukkan tidak berbeda nyata menurut uji $\mathrm{BNT}_{0,05}$

Tabel 8 menunjukkan bahwa nilai interaksi indeks stabilitas agregat tertinggi dijumpai pada perlakuan kombinasi pupuk kandang 10 ton ha ${ }^{-1}+$ NPK $400 \mathrm{~kg} \mathrm{ha}^{-1}$ yakni 60,01 dengan kriteria agak mantap yang berbeda nyata dengan perlakuan lainnya. Sementara nilai indeks stabilitas agregat terendah yaitu 51,69 dijumpai pada perlakuan pupuk kandang 10 ton ha ${ }^{-1}$. Hasil interksi perlakuan pembenah tanah dan pola tanam menunjukkan nilai indeks stabilitas agregat pada kriteria agak mantap. Hal ini sejalan dengan Goenadi (2006), yang menyebutkan bahwa bahan organik berpengaruh terhadap sifat fisik tanah yaitu dapat meningkatkan stabilitas agregat tanah, sehingga menciptakan struktur tanah yang mantap dan ideal bagi pertumbuhan tanamann yang berakibat pada tingkat porositas yang baik dan mengurangi tingkat kepadatan tanah.

Sedangkan interaksi pola tanam berpengaruh terhadap perubahan sifat indeks stabilitas agregat tanah terdapat pada perlakuan monokultur kedelai hal ini dikarenakan tanaman kedelai terdiri atas akar tunggang dan akar sekunder yang tumbuh dari akar tunggang, serta akar cabang yang tumbuh dari akar sekunder sehingga berpengaruh terhadap sifat fisika indeks stabilitas agregat. Hal ini seperti yang dinyatakan Andrianto dan Indarto (2004), susunan akar kedelai pada umumnya baik, pertumbuhan akar tunggang lurus masuk ke dalam tanah dan mempunyai banyak akar cabang pada akar-akar cabang terdapat bintil-bintil akara 
berisi Rhizobium jafonicum,yang mempunyai kemampuan mengikat zat lemas bebas $\left(\mathrm{N}_{2}\right)$ dari udara yang kemudian dipergunakan untuk menyuburkan tanah.

\section{Kadar Air Tanah}

\section{Pengaruh Pemberian Pembenah Tanah dan Pola Tanam terhadap Kadar Air Tanah pada $\mathrm{pF} 2,54$ dan $\mathrm{pF} 4,2$}

Hasil analisis ragam menunjukkan bahwa perlakuan pembenah tanah dan pola tanam tidak berpengaruh nyata terhadap kadar air pada $\mathrm{pF} 2,54$ dan $\mathrm{pF} 4,2$. Nilai rata-rata kadar air tanah pada $\mathrm{pF}$ 2,54 dan $\mathrm{pF}$ 4,2 dapat dilihat pada Tabel 9 dan 10.

Tabel 9. Nilai rata-rata kadar air tanah $\mathrm{pF} 2,54$ dan $\mathrm{pF} 4,2$ akibat pengaruh pembenah tanah

\begin{tabular}{|c|c|c|c|}
\hline \multirow{2}{*}{ Perlakuan Pembenah tanah } & \multicolumn{2}{|c|}{ Kadar air tanah $(\%)$} & \multirow{2}{*}{ Air Tersedia } \\
\hline & $\mathrm{pF} 2,54$ & $\mathrm{pF} 4.2$ & \\
\hline NPK $400 \mathrm{~kg} \mathrm{ha}^{-1}$ & 38.63 & 19.41 & 19.22 \\
\hline Biochar 10 ton $\mathrm{ha}^{-1}$ & 38.80 & 19.64 & 19.16 \\
\hline Pupuk kandang 10 ton $\mathrm{ha}^{-1}$ & 38.70 & 19.33 & 19.37 \\
\hline Biochar 10 ton $\mathrm{ha}^{-1}+\mathrm{NPK} 400 \mathrm{~kg} \mathrm{ha}^{-1}$ & 38.93 & 19.61 & 19.32 \\
\hline Pupuk kandang 10 ton $\mathrm{ha}^{-1}+$ NPK $400 \mathrm{~kg} \mathrm{ha}^{-1}$ & 39.26 & 19.76 & 19.50 \\
\hline BNT $_{0,05}$ & - & - & \\
\hline
\end{tabular}

Hasil analisis ragam menunjukkan kadar air tanah $\mathrm{pF}$ 2,54 dan $\mathrm{pF}$ 4,2 tidak berbeda nyata antar perlakuan hal ini diduga disebabkan oleh dosis biochar dan pembenah tanah yang diberikan pada tahun pertama belum mampu meningkatkan kapasitas kadar air tanah.hal ini sesuai dengan penelitian Sinulingga dan Darmanti (2008) semakin banyak pemberian bahan pembenah tanah pada tanah pasir maka air semakin banyak ditahan oleh tanah, pemberian biochar dan bahan pembenah tanah tidak secara konsisten memberikan pengaruh yang nyata terhadap kadar air titik layu permanen $\mathrm{pF} 4,2$.

Tabel 10. Nilai rata-rata kadar air tanah $\mathrm{pF} 2,54 \mathrm{pF}$ dan $\mathrm{pF} 4,2$ akibat pengaruh pola tanam

\begin{tabular}{lccc}
\hline \multirow{2}{*}{ Perlakuan Pola tanam } & \multicolumn{2}{c}{ Kadar air tanah $(\%)$} & \multirow{2}{*}{ Air Tersedia } \\
\cline { 2 - 3 } & $\mathrm{pF} 2,54$ & $\mathrm{pF} \mathrm{4.2}$ & \\
\hline Monokultur Jagung & 36.21 & 18.21 & 18.00 \\
Monokultur Kedelai & 36.67 & 18.58 & 18.09 \\
Tumpangsari Jagung dan Kedelai & 38.85 & 19.40 & 19.45 \\
\hline BNT $_{\mathbf{0}, 05}$ & - & - & - \\
\hline
\end{tabular}

Tabel 10 menunjukkan rata-rata nilai kadar air tanah akibat perlakuan pola tanam pada pF 2,54 tertinggi pada perlakuan tumpangsari jagung dan kedelai yaitu 38,85\% tidak berbeda nyata dengan perlakuan monokultur kedelai, dan terendah pada perlakuan monokultur jagung dengan nilai $36,21 \%$. Sedangkan rata-rata nilai kadar air tanah akibat perlakuan pola tanam pada $\mathrm{pF}$ 4,2 tertinggi pada perlakuan tumpangsari jagung dan kedelai dengan nilai $19,40 \%$ yang berbeda nyata dengan perlakuan monokultur kedelai dan terendah pada perlakuan monokultur jagung dengan nilai $18,21 \%$. 


\section{KESIMPULAN DAN SARAN}

\section{Kesimpulan}

Perlakuan pupuk organik, biochar, NPK dan pola tanam tidak memberikan efek yang nyata terhadap karakteristik porositas tanah, indeks stabilitas agregat tanah dan kadar air tanah. Namun terdapat interaksi antara perlakuan pupuk organik, biochar, NPK dan pola tanam terhadap porositas tanah dan indeks stabilitas agregat.

\section{Saran}

Untuk mengetahui peran pupuk organik, biochar, NPK dan pola tanam dalam memperbaiki karakteristik sifat fisika tanah perlu dilakukan penelitian lanjutan pada lahan yang telah mengandung residu bahan pembenah tanah untuk musim tanam kedua dan selanjutnya.

\section{DAFTAR PUSTAKA}

Balai Penelitian Tanah. 2003. Petunjuk Teknis Evaluasi Lahan untuk Komoditas Pertanian. Balai Penelitian Tanah. Bogor.

Hardjowigeno, S. dan Widiatmaka. 2007. Evaluasi Kesesuaian Lahan dan Perencanaan Tata Guna Lahan. Gadjah Mada University Press. Yogyakarta.

Lingga, P. 2008. Petunjuk Penggunaan Pupuk. Penebar Swadaya. Depok.

Lingga, P. dan Marsono, 2007. Petunjuk Penggunaan Pupuk. Edisi Revisi Penebar Swadaya, Jakarta.

Hardjowigeno, S., 2003. Klasifikasi Tanah Dan Pedogenesis. Akademika Pressindo, Jakarta.

Shenbagavalli, S. and Mahimairaja, S. 2012. Production and characterization of biochar from different biological wastes. International Journal of Plant, Animal, and Environmental Sciences 2(1): $197-201$.

Mulyani,S. 2002. Pupuk dan Cara Pemupukan. Rineka Cipta, Jakarta.

Hakim, N., M. Y., Nyakpa, A. M. Lubis, S. G. Nugroho, M. A. Dina, G. B. Hong, H. H. Bailey. 2006, Dasar-Dasar Ilmu Tanah. Penerbit Universitas Lampung, Lampung.

Adisarwanto, T; 2005. Kedelai. Penebar Swadaya, Jakarta.

Goenadi, D.H. 2006. Pupuk dan Teknologi Pemupukan Berbasis Hayati dari Cawan Petri ke Lahan Petani. Yayasan John Hi-Tech. Idetama. Jakarta.

Sutedjo, M. M., dan A. G. Kartasapoetra. 1990. Pupuk dan Cara Pemupukan. Rineka Cipta, Jakarta. 